\title{
Pre-Scaling up of Improved Maize Varieties in Essera and Boloso Sore Woreda of Southern Nation Nationalities and Peoples Regional State, Ethiopia
}

\author{
Abdirazak Abdala ${ }^{1 *}$ and Bereket Tufo ${ }^{2}$ \\ ${ }^{1}$ Areka Agricultural Research Center, Ethiopia \\ ${ }^{2}$ Southern Agricultural Research Institute, Ethiopia
}

Submission: July 05, 2018, Published: August 09, 2018

"Corresponding author: Abdirazak Abdala, Areka Agricultural Research Center, 079 PO.BOX Areka, Ethiopia, Tel: 916390047; Email: a.abdala75@yahoo.com; zebebaabdi@gmail.com

\begin{abstract}
The study was conducted in Dawro Zone, Essera Woreda and Wolaita Zone, Boloso sore Woreda on farmers' site. The objective of the study is to pre-scale up and popularize the best performing maize released variety in the study area. Thirty farmers were selected from each kebele (30x2, Hagel 01 and Dogewoybo plus 1FTC in Dogewoybo kebele) of the selected Woreda during the meher season of the year2017.From a total of 60 farmers male represents 42 and female 18. During farmers' selection process both female and male farmers had been incorporated so as to avoid gender bias. Training was given for the selected farmers, development agents and Woreda experts about improved maize technologies production and management. Full packages of the technologies were provided. Variety (BH546) were planted in 0.25ha of each plotted land of farmers' site in Hagel 01 kebele in Essera woreda \& Variety (BH547) were planted in 0.25ha of each plotted land of farmers' site in Dogewoybo kebele in Boloso sore Woreda. The recommended rate of NPS, UREA and Seed rate used were $100 \mathrm{~kg}, 100 \mathrm{~kg}$ and $25 \mathrm{~kg}$ per hectare respectively. Farmers evaluated and selected the varieties depending on their criteria's. The ranking procedure was explained for participant farmers and each selection criterion was ranked from 1 to 5 (1=Very poor, 2= Poor, 3= Good, 4= Very good and 5= Excellent).

Then farmers were given the chance to rank the variety (BH546 in Essera woreda and BH547 in Boloso sore woreda) based on the attributes listed by them. The criteria's were Earliness, seed/grin size, grain color, resistance to disease, marketability, resistance to shattering and lodging, number of cobs, length of cobs, husk length and Grain yield. The result showed that there was a good yield (BH546) in Essera and in Boloso sore Woreda. Local variety was not used. Mean grain yield in qt/ha from BH546 in Essera woreda in Hagel 01 was 63.71 and whereas, varieties (BH547) in Boloso sore in Dogewoybo kebele was 34.29. The variety BH546 was recorded high yield in Essera woreda. But based the farmers' selection criteria and grain yield, both varieties means, variety (BH546) in Essera woreda and variety (BH547) in Boloso sore woreda were selected. Therefore, both BH546 and BH547 varieties were recommended for further pre-scaling up in the study areas in Essera and Boloso sore respectively, as well as in other areas of similar agro-ecologies.
\end{abstract}

Keywords: BH546; BH547; Improved Variety

Abbreviations: SNNPRS: Southern Nation National People Regional State; NPS: N: Nitrogen; P: Phosphorus; S: Sulfur

\section{Background and Justification}

Food security in Ethiopia, and elsewhere in Africa, is a major socio-political issue. Its economic wellbeing is also dependent on the success of its agriculture. Ethiopia has long suffered from food shortages and economic underdevelopment even though it is endowed with a wide range of crop and agro ecological diversity. Maize is the most important staple in terms of calorie intake in rural Ethiopia. The 2004/5 national survey of consumption expenditure indicated that maize accounted for $16.7 \%$ of the national calorie intake followed by sorghum (14.1\%) and wheat (12.6\%) among the major cereals [1]. Compared to the 1960s the share of maize consumption among cereals more than doubled to nearly $30 \%$ in the 2000s, whereas the share of teff, a cereal that occupies the largest area of all crops in Ethiopia, declined from more than 30\% to about $18 \%$ during the same period [2].The popularity of maize in Ethiopia is partly because of its high value as a food crop as well as the growing demand for the Stover as animal fodder and source of fuel for rural families. Approximately $88 \%$ of maize produced in Ethiopia is consumed as food, both as green and dry grain. Maize for industrial use has also supported growing demand. Very little maize is currently used as feed but this tool is changing in order 
to support a rapidly growing urbanization and poultry industry. There is evidence that the increased productivity and production of maize is also having a significant positive impact on poverty reduction [3].

In the study area, Essera \& Boloso sore Woreda the production and productivity was low even compared with the country productivity even though the area has high potential since access to newly released improved maize varieties was limited and both farmers and DAs have less awareness about newly released technologies and its production systems. Therefore, an introduction as well as participatory popularization and pre-scaling up of the improved maize variety in the area was critical. Thus, the purpose of this research was in order to increase production and productivity of maize production through participatory, popularization, selection, transfer and pre-scaling up of the maize variety.

\section{Objectives}

\section{General objective}

a. To pre-scale up and popularize the improved better yielding newly released maize varieties on Farmers' Training Centers and on the farmers' land around FTCs found under different agro-ecological Zones.

\section{Specific objective}

a. To recommend the new varieties which are suitable for the different agro-ecological zones and with better performance under optimum management conditions.

b. To develop the knowledge, skill and attitude of extension workers on the merits of the new varieties.

c. To increase awareness for different stakeholders involved (farmers, women, youth, school children, and other actors) on best production practice.

\section{Materials and Methods}

\section{Description of the study area}

The research was carried out in Essera districts of Dawro Zone and Bolos sore woreda of Wolaita zone, Southern Nation National People Regional State (SNNPRS). In Essera Woreda at Hagel 01 kebele and in Bolos sore woreda at Dogewoybo kebele respectively.

\section{Wolaita zone}

Wolaita Zone of Boloso sore Woreda is located in $420 \mathrm{~km}$ from Addis Ababa which is the capital city of Ethiopia, $158 \mathrm{~km}$ from Hawassa which is the capital city of the Region. The total land area of the woreda is 28,800 . It is characterized with high land $(17 \%)$, mid land (83\%) agro ecology (BSWARD offices, 2014). The altitude of the woreda ranges 1500-2500m.a.s.l (FAO, 2003).The average temperature varies between 10 to 20 . Rain is occurs during June to August and September is a transitional period between rainy and dry season and the annual rain fall of the Woreda is $1201 \mathrm{~mm}$ to $1600 \mathrm{~mm}$ (Wolaita Zone Metrological offices, 2014).

\section{Dawro zone}

Dawro zone of Essera Woreda is characterized with high land, mid land and lowland agro ecology with altitude of 2850, 2000 and 650meter respectively mean above sea level and an average annual RF of $600 \mathrm{~mm}-2300 \mathrm{~mm}$.Its annual average temperature 23.5 cowith minimum and maximum temperature of $18 \mathrm{co}$ and 29co respectively.

\section{Experimental design}

As the target area, two AGP woreda was selected purposively for the implementation of the activity. Two maize growing potential kebele were selected from each woreda. Having thirty (30) members with the composition of men, women and youth farmers was established in each kebele in addition to its' FTC. A total of 60 farmers ( 60 members $\mathrm{X}$ in 2 kebele of 2 districts) and 2FTC were participated in the activity. Out of thirty participants of each kebele, nine female participants were included and a total of eighteen female participants in the districts. Farmers were considered as replications i.e. the pre-scaling up and popularization activity was replicated on thirty farmers per kebele. One improved maize variety (BH546 in Essera woreda of Hagel 01 kebele \& BH547 in Bolos sore woreda of Dogewoybo kebele) were planted on selected farmers' plot $(20 \mathrm{mx} 10 \mathrm{~m})$ in 2017 Meher Season. The varieties were treated with full recommended maize production and management packages. The seed rate was $25 \mathrm{~kg} / \mathrm{ha}$ and fertilizer rate was $1: 1 \mathrm{~kg} / \mathrm{ha}$ NPS/UREA with split application of nitrogen: $1 / 3$ at planting time and $2 / 3$ at tillering stage of the crop.

After packaging and distribution of maize technologies \& other agricultural inputs, regular field visit by extension agents, joint field visit and supervision at different crop stage was carried out. Field day and popularization were organized and the varieties were pre-scaled up and evaluated jointly by farmers, agricultural experts, development agents and researchers to show performance of varieties at crop maturity stage.

Agronomic, yield data and the farmers' opinions, ideas, perceptions, interest and views were collected. Then farmers were given the chance to rank each variety based on the attributes listed by them. Both female and male farmers had been incorporated so as to avoid gender bias during farmers' selection process. The farmers' main selection criterion's used were Earliness, Drought Resistance, and Résistance to lodging, Seed Color, Seed Size, Straw Biomass, Disease Resistance, Grain Yield and Marketability. Each selection and evaluation criteria were rated using the rating scale: $1=$ Very poor $2=$ Poor $3=$ Good $4=$ Very Good $5=$ Excellent. R-software was used as statistical package (descriptive statistics were used to analyze the data). Finally the varieties were ranked in the order of their importance based on farmers' preference mean Score.

\section{Result and Discussion}

The number of participants during field day were male 99 female 30 total 129 , Civil servant male 12 female 3 total 15.Capacity 
building (training) have been given for number of farmers male: 323 female: 91 total 414 and number of experts and DAs male: 79; female: 7; total 86.Capacity building training was given on improved maize technology, common bean, faba bean, teff, chick pea and other varieties total package production system training has been given. The result showed that variety BH546 was the best yielder with seed yield of 63.71 quintal per hectare in Essera

Table 1: Average Maize Productivity (Yield in quintal per hectare) in Essera Woreda (Hagel 01 Kebele) and Boloso sore woreda (Dogewoybo kebele).

\begin{tabular}{|c|c|c|c|c|c|c|c|c|c|}
\hline \multicolumn{5}{|c|}{ Essera Woreda Hagel 01 Kebele (Quintal per Hectare) } & \multicolumn{5}{|c|}{ Bolos Sore Woreda Dogewoybo Kebele (Quintal per Hectare) } \\
\hline Variety $(\mathrm{N}=21)$ & Mean & Std error of mean & Min & Max & Variety $(\mathrm{N}=14)$ & Mean & Std error of mean & Min & Max \\
\hline BH546 & 63.71 & 2.17 & 50.63 & 84.38 & BH547 & 34.29 & 1.373 & 24 & 40 \\
\hline
\end{tabular}

Means with different superscript are statistically significant at $p<0.05$.

The participant farmers were listed the traits of their interest and scored each of the traits based on the rate given which is 1 up to 5. After scoring, each value of the score were added and divided to the number of the traits listed by the farmer. As the result in the Table showed above that mean scores of the variety BH546 and BH547 were 4.42 and 4.25 respectively because of the differences between the individual score of the traits. Variety BH546 has got highest mean score value in Essera woreda while BH547 has got Table 2: Farmers' perception in Essera and Bolos sore woreda (Dogewoybo and Hagel 01) kebele.

\begin{tabular}{|c|c|c|c|}
\hline \multirow{2}{*}{ No. } & \multirow{2}{*}{ Socio-Economic Characteristics } & \multirow{2}{*}{$\begin{array}{c}\text { Score Given (1-5) Dogewoybo Kebele } \\
\text { BH547 }\end{array}$} & \multirow{2}{*}{$\frac{\text { Score Given (1-5) Hagel } 01 \text { Kebele }}{\text { BH546 }}$} \\
\hline & & & \\
\hline 1 & Earliness & 4 & 2 \\
\hline 2 & Drought resistance & 4 & 4 \\
\hline 3 & Disease tolerance & 2 & 4 \\
\hline 4 & Lodging tolerance & 4 & 5 \\
\hline 5 & Vegetative growth & 4 & 4 \\
\hline 6 & Grain Yield & 5 & 5 \\
\hline 7 & Grain Size & 5 & 4 \\
\hline 8 & Grain Color & 5 & 5 \\
\hline 9 & No of cobs & 4 & 5 \\
\hline 10 & Husk length & 5 & 5 \\
\hline 11 & Length of cobs & 5 & 5 \\
\hline 12 & Marketability & 4 & 5 \\
\hline 13 & Taste of flour & - & - \\
\hline & Average & 4.25 & 4.42 \\
\hline
\end{tabular}

\section{Conclusion \& Recommendation}

Therefore, based on the farmers' preference criteria and grain yield variety BH546 was selected in Essera woreda Hagel 01 kebele. Based on the farmers' preference and grain yield as result shown the variety BH546 was recommended with its full packages in Essera woreda as well as in similar agro ecology. Based farmers' preference criteria and grain yield as result shown the improved variety BH547 was recommended with its full packages in the studying area and in similar agro ecology as well.

Generally, based on the farmers' preference \& grain yield as result shown the improved variety BH546 and BH547 were highest mean score value in Boloso sore woreda and selected for further pre-scaling by farmers. For variety BH546 highest score (5) recorded for Lodging tolerance, grain yield, grain color, number of cobs, husk length, length of cobs and marketability while for variety BH547 highest score (5) recorded for grain yield, grain size, grain color, number of cobs, husk length, length of cobs in Essera and Boloso sore woreda respectively (Table 2). woreda in Hagel 01 Kebele and BH547 was the best yielder with the seed yield of 32.29 quintal per hectare in Boloso sore woreda Dogewoybo kebele at the farmers farm respectively. But the study did not include local check because the study were about prescaling and popularizing the improved variety BH546 and BH547 in Essera and Boloso sore woreda respectively (Table 1). 


\section{References}

1. Berhane G, Paulos Z, Tafere K, Tamru S (2011) Food grain consumption and calorie intake patterns in Ethiopia. Addis Ababa: IFPRI. p: 18.

2. Demeke M (2012) Analysis of incentives and disincentives for maize in Ethiopia. Technical notes series, MAFAP. Rome: FAO. p: 36.

DOI:_10.19080/ARTOAJ.2018.17.556019
3. Dercon S, Gilligan DO, Hoddinott J, Woldehanna T (2009) The impact of agricultural extension and roads on poverty and consumption growth in fifteen Ethiopian villages. American Journal of Agricultural Economics 91(4):1007-1021.

Your next submission with Juniper Publishers
will reach you the below assets
- Quality Editorial service
- Swift Peer Review
- Reprints availability
- E-prints Service
- Manuscript Podcast for convenient understanding
- Global attainment for your research
- Manuscript accessibility in different formats
( Pdf, E-pub, Full Text, Audio)
- Unceasing customer service
Track the below URL for one-step submission
https://juniperpublishers.com/online-submission.php

